\title{
CHARACTERIZATION OF SOME UPLAND COTTON VARIETIES USING AFLP AND NIR TECHNIQUES
}

\author{
BASEL SALEH
}

Atomic Energy Commission of Syria, Damascus

SALEH, B.: Characterization of some upland cotton varieties using AFLP and NIR techniques. Agriculture (Pol'nohospodárstvo), vol. 58,2012 , no. 3, pp. 85-92.

This study was performed to assess genetic variability and chemical components of five upland cotton (Gossypium hirsutum L.) varieties grown in Syria using AFLP and NIR techniques. These varieties present considerable interest for genetic studies and plant improvement. Twenty-one AFLP PCs primer combinations yielded 1,017 discernible loci of which 495 $(50.569 \%)$ were polymorphic. Selected markers/primer pairs were ranged between 22 (E-AGA/T-GAA) and 89 (E-GAA/ T-CTT) fragments with an average of 48.429 fragments per primer pair. Marker Index (MI) average for AFLP markers was estimated to be 5.036. Our data revealed that both techniques gave relatively similar results regarding the degree of relatedness among the tested varieties. The pattern generated in NIR technique partially correlated with the other one revealed by AFLP technique. Summarizing all results obtained from NIR and AFLP techniques, we could conclude that chemical structure was relatively reflected in genetic variation among the tested cotton varieties.

Key words: AFLPs, cotton, genetic variability, NIR, polymorphism, variety

Cotton is an economically important plant grown world-wide as a principal source of staple fiber and vegetable oil. A great deal of effort has been made to improve cotton cultivation and characteristics by breeders. Cotton is one of the major fiber crops in Syria, with a cultivated area amount to 125,000 hectares, and a production of 470,000 tons of seed cotton and lint production is estimated at 160,000 tons. Yarn spinning capacity is estimated at 180,000 tons (USDA 2011).

The introduction of Near Infrared Spectroscopy (NIR) since 1973 (Williams 2002; Wesley et al. 2008; Munck 2009), has fundamentally changed the economy of quality assessment for both plant breeders grain and food industry. NIR can be used for sample classification without the need for commercial calibrations which requires minimum of training and has the potential of being even more important than prediction of specific quality traits (Munck 2009). Recent application in NIR technology by "data breeding" demonstrated manual selection for complex high-quality traits and seed genotype directly from a PCA (Principal Component Analysis) score plot. New equipment makes automatic analysis and sorting for complex quality traits possible, both in bulk and on single seed basis. Previously, combination of NIR and DNA mapping was evaluated by PCA in maize (Wilson et al. 2004). Yet, NIR technique was used in cotton characterization for many parameters (Kohel 1998; Lordelo et al. 2008; Fortier et al. 2012). NIR spectroscopy is used routinely for the compositional, functional, and sensory analysis of food ingredients, process intermediates, and final products. The major advantage of NIR is that no sample preparation is usually necessary; hence the analysis is very simple and very fast (between 15 and $90 \mathrm{sec}$ ) and can be carried out on-line.

In this investigation, NIR technique was applied in order to support the results of AFLP in cotton genotyp-

Basel Saleh, Department of Molecular Biology and Biotechnology, Atomic Energy Commission of Syria, P.O. Box 6091, Damascus, Syria. E-mail: ascientific@aec.org.sy 
ing. The genetic relationship among cotton genotypes has been extensively studied based on PCR-based markers e.g. AFLPs (Abdalla et al. 2001; Hussein et al. 2002, 2007; Rana et al. 2005; Adawy et al. 2006; Khalighi et al. 2008; Badigannavar et al. 2010), SSR (Adawy 2007; Hussein et al. 2007; Kalivas et al. 2011), microsatellite (Adawy 2007; Hussein et al. 2006) and RAPD (Hussein et al. 2007; Chaudhary et al. 2010).

Most variability/taxonomic affinity studies in cotton focused mainly on morphology and nuclear DNA diversity. While, only few studies evaluated the chemical components analysis. Aleppo118, Aleppo33/1, Aleppo90, Raqqa5, and Deir-Ezzor22 cotton (Gossypium hirsutum L.) varieties present considerable interest for genetic studies and plant improvement. In this paper, the use of NIR and AFLP technologies was reported to assess genotype and phenotype relationship among tested varieties.

The major aim of the General Commission for Scientific Agricultural Research, Damascus, Syria (GCSAR) programs was to increase cotton yield and to develop line quality, increase protein and oil contents of seeds, select the most adapted ones under local environmental conditions which could be integrated in a hybridization and breeding program, and improve biotic and abiotic stress tolerance.

\section{MATERIAL AND METHODS}

\section{Plant materials}

Seeds of five Upland cotton ( $G$. hirsutum L.) varieties, Aleppo118, Aleppo33/1, Aleppo90, Raqqa5, and Deir-Ezzor22 were collected from the General Commission for Scientific Agricultural Research, Damascus, Syria (GCSAR). Table 1 shows genetic description of all five varieties characterized in this study.

\section{DNA extraction}

The genomic DNA of the plant was extracted from young leaves of five upland cotton varieties grown in Syria (bulk of 5 leaves/variety for each representative variety) by a CTAB (cetyltrimethylammonium bromide) protocol as described by Doyle and Doyle (1987) with minor modifications.

Leaves tissue $(150 \mathrm{mg})$ were ground in liquid nitrogen, the powder was transferred to a $2 \mathrm{ml}$ Eppendorf tube, mixed with $900 \mu 1$ of extraction buffer $(100 \mathrm{mM}$
Tris-HCl, pH 8.0, 1.4 M NaCl, 20 mM EDTA, 0.0018 $\mathrm{ml} \beta$-mercaptoethanol, 2\% CTAB), and incubated at $65^{\circ} \mathrm{C}$ for $20 \mathrm{~min}$. DNA was extracted with one volume of a chloroform:isoamyl alcohol mix $(24: 1, \mathrm{v} / \mathrm{v})$ and centrifuged at $12,000 \mathrm{~g}$ for $10 \mathrm{~min}$ at $4^{\circ} \mathrm{C}$. The aqueous phase was transferred to a fresh tube, and the DNA was precipitated with an equal volume of cold isopropanol and kept at $20^{\circ} \mathrm{C}$ for $10 \mathrm{~min}$. Then centrifuged at $12,000 \mathrm{~g}$ for $10 \mathrm{~min}$ at $4^{\circ} \mathrm{C}$, the supernatant was discarded, DNA was then spooled out and washed with 1 $\mathrm{M}$ ammonium acetate and $100 \%$ ethanol. The cleaned DNA pellet was air dried and dissolved in $100 \mu \mathrm{l}$ of $0.1 \mathrm{X}$ TE buffer (1 mM Tris-HCl, $0.1 \mathrm{mM}$ EDTA, $\mathrm{pH}$ $8.0)$. After addition of $5 \mu \mathrm{l}$ of RNase $(10 \mathrm{mg} / \mathrm{ml})$, and incubation for $30 \mathrm{~min}$ at $37^{\circ} \mathrm{C}$, the DNA concentration was quantified by DNA fluorimeter and kept at $-80^{\circ} \mathrm{C}$ until use.

\section{AFLP assay}

AFLP analyses were performed according to Vos et al. (1985) with a minor modification. Template DNA preparation of $130 \mathrm{ng}$ was restricted with 0.1 $\mathrm{U} / \mu \mathrm{l}$ MseI/Tru91 and $0.1 \mathrm{U} / \mu \mathrm{l}$ Pst $/$ EcoR1 (Promega) (a rare 6-base cutter) and ligated to $M s \mathrm{eI} /$ Tru 91 adaptor $(0.25 \mathrm{pmol} / \mu \mathrm{l})$ and $P$ st $\mathrm{I} /$ EcoR 1 adaptor $(0.25 \mathrm{pmol} / \mu \mathrm{l}), 0.2 \mathrm{mM} \mathrm{rATp}$ and $0.065 \mathrm{U} / \mu \mathrm{T} \mathrm{T} 4$ DNA overnight at $37^{\circ} \mathrm{C}$, in a total volume of $20 \mu \mathrm{l}$.

An inactivation of restriction endonuclease has been done by incubating the mixture at $70^{\circ} \mathrm{C}$ for 15 min. After checking for complete digestion, the digested DNA was stored at $4^{\circ} \mathrm{C}$ until required. Preamplification of DNA fragments was performed using non-selective primer combination in a total volume of $50 \mu \mathrm{l}$. Pre-amplification reaction was carried out as follows: $5 \mu \mathrm{l}$ of ligated DNA, $0.3 \mu \mathrm{mol}$ of each primers PstI/EcoR1 and MseI/Tru91 (MWV, Germany), $1.25 \mathrm{mM} \mathrm{MgCl}{ }_{2}, 0.3 \mathrm{mM}$ dNTP (Promega), and $0.05 \mathrm{U}$ of Taq DNA polymerase (Promega). The primers used were MseI (GACGATGAGTCCTGAGTAA) and EcoRI (GACTGCGTACCAATTC). Samples were run in a thermal cycler programmed for the first 12 cycles; the thermal profile was $94^{\circ} \mathrm{C}$ for $30 \mathrm{~s}, 65^{\circ} \mathrm{C}\left(-0.7^{\circ} \mathrm{C} /\right.$ cycle $)$ for $30 \mathrm{~s}$, and $72^{\circ} \mathrm{C}$ for $60 \mathrm{~s}$. For the last 23 cycles, the annealing temperature $\left(\mathrm{aT}^{\circ}\right)$ was set to $56^{\circ} \mathrm{C}$ for $30 \mathrm{sec}$, and $72^{\circ} \mathrm{C}$ for $1 \mathrm{~min}$. Pre-amplification products were then diluted 50 -folds in double-distilled $\mathrm{H}_{2} \mathrm{O}$, and used as templates for selective amplification. 
Selective amplification of the pre-amplified DNA was carried out using various selective primer combinations. This last amplification was performed in $25 \mu \mathrm{l}$ reaction volume containing $5 \mu \mathrm{l}$ of diluted DNA pre-amplified, 10X PCR buffer without $\mathrm{MgCl}_{2}, 0.5 \mathrm{ng}$ of $P s t \mathrm{I} / E c o$ R 1 selective primer, $1.5 \mathrm{ng}$ of $M s e \mathrm{I} / \mathrm{Tr} u 91$ selective primer, $1.5 \mathrm{mM}$ of $\mathrm{MgCl}_{2}, 0.2 \mathrm{mM}$ dNTP and $0.04 \mathrm{U}$ of Taq DNA polymerase. PCR reactions for selective amplification were performed in a thermal cycler programmed as follows: $94^{\circ} \mathrm{C}$ for $30 \mathrm{sec}, 65^{\circ} \mathrm{C}$ $\left(-0.7^{\circ} \mathrm{C} /\right.$ cycle $)$ for $30 \mathrm{sec}$ and $72^{\circ} \mathrm{C}$ for $1 \mathrm{~min}$ for the first 14 cycles. For the last 24 cycles, the annealing temperature $\left(\mathrm{aT}^{\circ}\right)$ was set to $56^{\circ} \mathrm{C}$ for $30 \mathrm{sec}$, and $72^{\circ} \mathrm{C}$ for $1 \mathrm{~min}$.

Amplification products were separated on a $6 \%$ polyacrylamide (acrylamide:bisacrylamide 19:1)/8 M urea sequencing gel (SequaGel ${ }^{\circledR}$ XR, National Diagnostics, Inc.) at $120 \mathrm{~W}$ for $2 \mathrm{~h}$ in $1 \mathrm{X}$ TBE buffer $(0.09$ $M$ Tris-borate and 0.002 M EDTA), and detected by silver staining according to the manufacturer's instructions (Sigma). Band sizes were determined by comparison with a $1 \mathrm{~kb}$ DNA ladder size standard.

\section{NIR assay}

The NIR technique is used for defining the physical seed quality. A range of complex functional food analysis aims at visualizing the technological trait important for industrial use of the final product. Seeds were milled to a fine powder and used as template for chemical analysis. Measurements of Principal Component Analysis (PCA) classification were done using Bruker Matrix I FT-NIR spectrometer (Bruker, Ettlingen, Germany) at NIR spectra $850-1,350 \mathrm{~nm}$.

\section{Data analysis}

To match more loci at the genomic level, twentyone AFLP PCs primer combinations were tested for detecting the polymorphism among the five cotton varieties. Data were scored manually as (1) for the presence and (0) for the absence of a DNA band for each locus in each variety tested. The found percent disagreement values (PDVs) were used to generate a matrix via the Unweighted Pair Group Mean Arithmetic average (UPGMA) using Statistica program (Statsoft 2003). This matrix was used to calculate similarity/genetic distance (Jaccard 1908). Polymorphic information content (PIC) values were calculated for each AFLP PCs primer combination according to the formula:

$$
\mathrm{PIC}=1-\Sigma\left(\mathrm{P}_{\mathrm{ij}}\right)^{2},
$$

where $P_{i j}$ is the frequency of the $i^{\text {th }}$ pattern revealed by the $\mathrm{j}^{\text {th }}$ primer summed across all patterns revealed by the primers (Botstein et al. 1980). The marker index was calculated for AFLP PCs primer combination as $\mathrm{MI}=\mathrm{PIC} \times \eta \beta$, where $\mathrm{PIC}$ is the mean PIC value, $\eta$ the number of bands, and $\beta$ is the proportion of polymorphic bands (Powell et al. 1996).

$\mathrm{T}$ a $\mathrm{b} 1 \mathrm{e} \quad 1$

Descriptive of five certificated cotton varieties used in this study

\begin{tabular}{|c|c|c|c|c|}
\hline Variety & $\begin{array}{l}\text { Agro-ecological } \\
\text { zone }\end{array}$ & $\begin{array}{r}\text { Yield }[\mathrm{kg} / \mathrm{ha}] \\
\text { upon certification }\end{array}$ & Certification year & Origin \\
\hline Aleppo118 & Aleppo - Idleb & 6,252 & 2004 & $\begin{array}{c}\text { Hybrid (Syrian var. Aleppo } 40 \times \text { American var. } \\
\text { BW 76-31) }\end{array}$ \\
\hline Aleppo33/1 & Hama - Homs & 5,166 & 1987 & Created from selected line Acala SG-4 \\
\hline Aleppo90 & Hassakeh & 5,130 & 1977 & $\begin{array}{c}\text { Hybrid (Russian var. Tashkand-3 } \times \text { American } \\
\text { var. Deltapine 70) }\end{array}$ \\
\hline Raqqa5 & Raqqa & 4,840 & 1988 & Created from selected Russian var. Tashkand-3 \\
\hline Deir-Ezzor22 & Deir Ezzor & 5,420 & 1988 & Created from selected American var. Deltapine 41 \\
\hline
\end{tabular}

Source: The General Commission for Scientific Agricultural Research, Damascus, Syria (GCSAR) 


\section{RESULTS AND DISCUSSION}

Twenty-one AFLP PCs primer pairs yielded 1,017 discernible loci of which 495 (50.569\%) were polymorphic. The designed AFLP PCs selected primer combinations list is presented in Table 2. Selected markers/primer pairs were ranged between 22 and 89 fragments with an average of 48.429 fragments per primer pair. Primer combinations E-GAA/T-CTT showed the highest number of fragments ( 89 amplicons), while EAGA/T-GAA primer combination revealed the least number (22 amplicons) (Table 2).

Hussein et al. (2007) found that 926 total amplicons with an average of 84.2 amplicons/PCs using 11 AFLP PCs in 11 cotton genotypes. Contrarily, Sharaf et al. (2009) reported that 110,70 , and 576 total amplicons with an average of $7.86,7$, and 113.4 amplicons/primer or PCs using 14 RAPD, 10 ISSR primers, and 5 AFLP PCs in cotton.

Khalighi et al. (2008) pointed out 533 AFLP loci with an average of $29.572 \mathrm{loci} /$ primer pair in AFLP analysis of 31 accessions belonging to the 15 species of wheat (Triticum spp). On the other hand, Saleh (2012a) reported that the thirteen AFLP PCs primer combinations selected generated a total number of 466 scorable bands of which 199 (45.527\%) were polymorphic, with an average of 35.846 amplicons/primer combination in AFLP analysis of some Syrian wheat (Triticum spp) varieties.

Number of polymorphic bands produced by AFLP marker varied between 6 (E-AGA/T-GAA AFLP PCs) and 43 (E-ACG/T-CTG AFLP PCs). The total number of observed polymorphic bands resulting in this study was 495 with an average of 23.571 polymorphic am-

$\mathrm{T}$ a b 1 e 2

Selected 21 AFLP PCs primer combinations tested in this study

\begin{tabular}{|c|c|c|c|c|c|}
\hline Primer combinations & TB & PB & $\mathrm{P}[\%]$ & PIC & MI \\
\hline E-CTA/T-GAT & 37 & 21 & 56.756 & 0.247 & 5.187 \\
\hline E-ACT/T-GAA & 48 & 13 & 27.083 & 0.107 & 1.391 \\
\hline E-AAG/T-GAC & 34 & 14 & 41.176 & 0.179 & 2.506 \\
\hline E-AAC/T-GTG & 48 & 15 & 31.250 & 0.123 & 1.845 \\
\hline E-CTT/T-GAG & 48 & 17 & 35.416 & 0.12 & 2.040 \\
\hline E-AAC/T-CTG & 34 & 19 & 55.882 & 0.24 & 4.560 \\
\hline E-CTT/T-GTC & 38 & 14 & 36.842 & 0.163 & 2.282 \\
\hline E-GAT/T-GTA & 30 & 26 & 86.667 & 0.363 & 9.438 \\
\hline E-AGA/T-GTT & 24 & 18 & 75.000 & 0.327 & 5.886 \\
\hline E-ACC/T-CTG & 45 & 32 & 71.111 & 0.273 & 8.736 \\
\hline E-GAC/T-GTC & 32 & 18 & 56.250 & 0.230 & 4.140 \\
\hline E-GAT/T-GAT & 46 & 20 & 43.478 & 0.181 & 3.620 \\
\hline E-AGA/T-GAA & 22 & 6 & 27.273 & 0.109 & 0.654 \\
\hline E-ACC/T-GAC & 44 & 29 & 65.909 & 0.244 & 7.076 \\
\hline E-ACG/T-CTG & 53 & 43 & 81.132 & 0.314 & 13.502 \\
\hline E-GAC/T-GAG & 41 & 19 & 46.314 & 0.176 & 3.344 \\
\hline E-GAG/T-GTT & 88 & 35 & 39.773 & 0.155 & 5.425 \\
\hline E-GAA/T-CTT & 89 & 32 & 35.956 & 0.148 & 4.736 \\
\hline E-AGG/T-GTG & 56 & 35 & 62.500 & 0.223 & 7.805 \\
\hline E-CTG/T-GTG & 81 & 37 & 45.679 & 0.178 & 6.586 \\
\hline E-CTT/T-CTA & 79 & 32 & 40.506 & 0.156 & 4.992 \\
\hline Total & 1,017 & 495 & - & - & - \\
\hline Mean & 48.429 & 23.571 & 50.569 & 0.203 & 5.036 \\
\hline
\end{tabular}

TB: Total bands, PB: Polymorphic bands, P [\%]: Polymorphic \%, PIC: Polymorphic information content, MI: Marker index 
plicons/primer pair. This represents a level of polymorphism of $50.569 \%$ (Table 2). These results were in accordance with Adawy et al. (2006) who used 16 AFLP primer combinations to investigate the genetic polymorphism among 21 cotton genotypes. The present results were also in accordance with the observation by Sharaf et al. (2009) who reported that the estimated polymorphism was $71.82 \%, 88.57 \%$, and $50.52 \%$ in genetic variability investigated among seven cotton genotypes using 14 RAPD, 10 ISSR primers, and 5 AFLP primer combinations.

The AFLP analysis revealed a total of 1,017 amplicons of which 495 were polymorphic, representing a level of polymorphism of $50.569 \%$ which is higher than that estimated by Hussein et al. (2007) (38.3\%) using the same markers.

However, it was lower than those found in the latter study (63.2\%) and also in Chaudhary et al. (2010) study (91.6\%) using RAPD markers. The level of detected polymorphism was also lower than those revealed by RAPD (71.82\%) and ISSR (88.57\%) (Sharaf et al. 2009). Badigannavar et al. (2010) reported that AFLP markers were applied to study genetic variability present in elite of 75 upland cotton genotypes related to several seed quality trait, where, AFLP fingerprint revealed 234 polymorphic AFLP loci.

The previous study demonstrated that the generation of AFLP amplicons ranges from 21 to 54 resulting in an average of 32.3 bands/primer pair. Such a high variation in the number of fragments produced by these AFLP PCs primer pairs could be attributed to the differences in the binding sites throughout genome of the included genotypes.

Abdalla et al. (2001) employed 16 AFLP primer combinations on three diploid species, G. herbaceum L. (A1), G. arbareum L. (A2), and G. raimondii Ulbrich (D5) and $26 \mathrm{AD}$ allotetraploid accessions ( $G$. barbadense and G. hirsutum). The previous report mentioned that UPGMA analysis of genetic similarities based on 368 polymorphic markers placed $25 \mathrm{AD}$ tetraploid cotton cultivars into two distinct monophyletic clodes that are in complete agreement with the traditional taxonomic arrangement.

Hussein et al. (2002) used 6 AFLP primer combinations to estimate the genetic variability among 12 Egyptian cotton varieties (G. barbadense) and one $G$. hirsutum. The level of polymorphism among all genotypes was $56.3 \%$. On the other hand, Rana et al. (2005) investigated the genetic diversity in 24 advanced breeding lines of cotton using six AFLP primer-pairs and 14 morphological characters. The six selected AFLP primer-pairs generated a total of 535 amplification products, of which 460 were found to be polymorphic giving $85.9 \%$ polymorphism. Moreover, Adawy et al. (2006) used AFLP technique to study the genetic relationships among 21 cotton genotypes from two different species G. barbadense and G. hirsutum. Fifteen primer combinations detected unique specific markers identifying 8 out of the 21 genotypes. Hussein et al. (2006) employed twenty-four microsatellite flanking primer pairs to investigate the genetic polymorphism, the number of alleles/primer ranged from 1 to 5 , while the number of polymorphic alleles varied from 0 to 5 and the average level of polymorphism was $53.7 \%$. Adawy (2007) however obtained 119 alleles among which 79 were polymorphic $(66.4 \%)$ by use of ESTSSR. The number of alleles/primer pair ranged from 1 to 6 with an average of 3.1, while the number of polymorphic alleles ranged from 0 to 5 with an average of 2.1 alleles/primer pair.

Due to the narrow genetic base of cotton germplasm that cotton breeders have been utilizing and low efficiency of traditional selection methods, cultivar improvement in cotton has slowed down in the past 10-15 years (May et al. 1995; Meredith 2000; Lewis 2001). PIC estimated values ranged between 0.107 and 0.363 with an average of 0.203 . In this respect, the low PIC values obtained through out this study may be attributed to the modern breeding coming from breeding programs employed in Syrian Arab Republic by GCSAR. Nevertheless, the growing public concern regarding the tremendous enhancements of yield by modern breeding together with a large decrease in diversity might threaten future selection progress. The GCSAR tested them under the local environmental conditions in order to select the most adapted ones which could be integrated in a hybridization and breeding program. Our PIC estimated values were somewhat lower than those reported by Kalivas et al. (2011) with an average PIC value 0.293 for 12 pairs of SSR primers, and a range between 0.032 and 0.548 . In the present study, estimated Marker Index (MI) average was 5.036.

The MI was lower than that detected by Sharaf et al. (2009), where it was estimated to be 79.52, 18.2, and 18.7 using AFLP, RAPD, and ISSR respectively in cotton. 
$\mathrm{T}$ a $\mathrm{b} 1 \mathrm{e} \quad 3$

Percent Disagreement Values (PDV) produced by the 21 AFLP PCs primers using UPGMA routine in statistical program

\begin{tabular}{|c|c|c|c|c|c|}
\hline Variety & A118 & A33/1 & A90 & Raq5 & DE22 \\
\hline A118 & 0 & & & & \\
A33/1 & 0.23 & 0 & & & \\
A90 & 0.2 & 0.19 & 0 & & \\
Raq5 & 0.18 & 0.26 & 0.18 & 0 & \\
DE22 & 0.27 & 0.35 & 0.3 & 0.24 & 0 \\
\hline
\end{tabular}

AFLP data produced genetic distances ranging from 0.18 to 0.35 with a mean of 0.24 (Table 3). The relationship of these varieties, as identified by the classification based on AFLP technique, has been represented as a dendrogram constructed by the UPGMA clustering method (Figure 1).

The dendrogram (Figure 1) demonstrated that the five cotton varieties phylogenetically fell into two main groups. The first cluster consisted of Deir-Ezzor22 variety that formed a distinct cluster with a PDV estimated value 0.29 (similarity 0.669 ) with other tested varieties, especially with Aleppo33/1 where $\mathrm{PDV}=0.35$ (similarity 0.617). The second cluster however included the remaining varieties. Subsequently, the previous cluster was further divided into two subclusters. The first subcluster involved Aleppo33/1 that was too genetically distinct from the other tested varieties where PDV $=0.26$ (similarity 0.698). Contrarily, the second

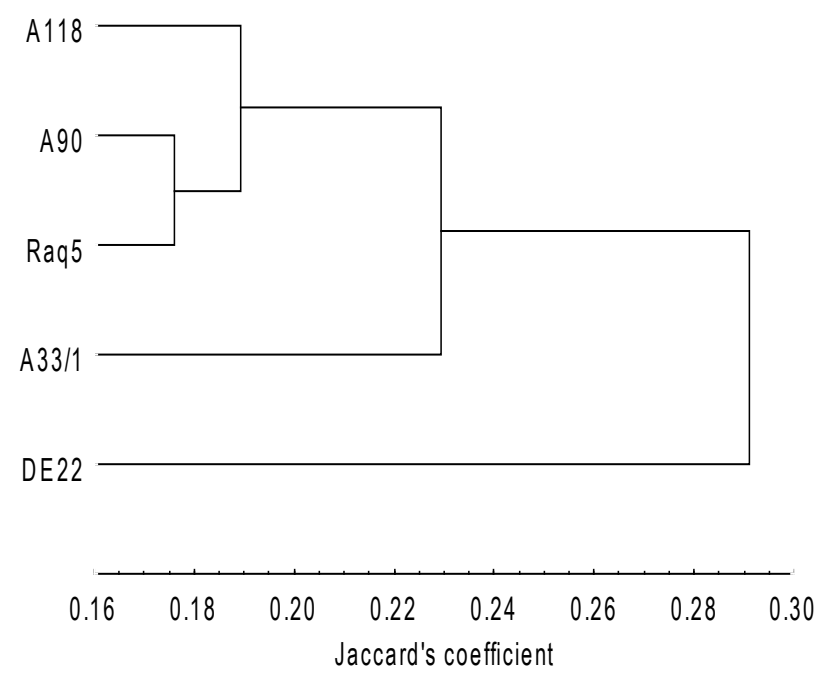

Figure 1. UPGMA cluster analysis-based on the PDV value for AFLPs fingerprints showing genetic relationship among the five Syrian cotton varieties subcluster included Aleppo90 \& Raqqa5 that were closely related to $\mathrm{PDV}=0.18$ (similarity 0.783 ). This subcluster was close to Aleppo118 at $\mathrm{PDV}=0.2$ (similarity 0.753 ) with Aleppo 90 and at $\mathrm{PDV}=0.18$ (similarity 0.773 ) with Raqqa5.

Regarding the estimated PDV values, it has been noticed that the overall average PDV for the five cotton varieties tested was 0.24 , where Deir-Ezzor 22 variety exhibited the highest PDV value (0.29). This value however ranged between 0.215 and 0.258 for the remaining tested varieties. Based upon the previous observation and according to the position of genotypes presented by UPGMA cluster analysis, it may however be postulated that Deir-Ezzor22 be suggested to present a distinct variety from the other varieties tested.

Otherwise, cottonseed is a major oilseed in domestic and international markets. Cotton is relatively well documented with classical genetic maps as well as by various types of PCR-based markers. However, limited work on biochemistry of cottonseeds has been done. The NIR approach interpreted by chemo metrics is an economic and promising tool for gene banks to define the genetic variation of physicalchemical traits in seeds. One of the simplest ways of using PCA is the score plot. NIR is considered to be one of the most promising techniques for evaluating seeds quality (Wesley et al. 2008).

On the other hand, the pattern generated for chemical spectra data illustrated in Figure 2 demonstrated that the five Syrian cotton varieties were clustered into two main clusters. The first contained Deir-Ezzor22 and Raqqa5 varieties, while, the second one involved Aleppo118, Aleppo90, and Aleppo33/1 that were closely related.

In Figure 2, sample distinctness for DeirEzzor22, Aleppo118, and Aleppo33/1 varieties could be probably attributed to the fact that it can be seen from the FT-NIR spectra of cotton that similar functional groups were observed but at different concentrations (unpublished data).

Other investigation demonstrated genotypic variation in salt tolerance present among these cotton varieties based upon various examined physiological indices (Saleh 2012b). The previous investigation mentioned that Deir-Ezzor22 and Raqqa5 varieties could relatively be classified as salt tolerant varieties compared to other tested varieties. In ad- 


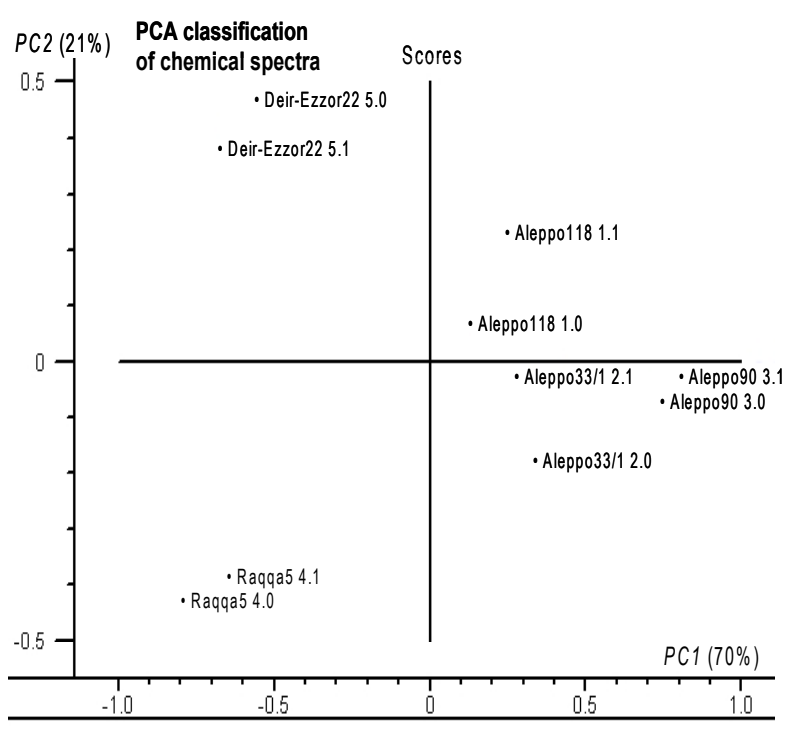

Figure 2. Principal Component Analysis (PCA) classification of NIR spectra analysis from five Syrian cotton varieties at $850-1,350 \mathrm{~nm}$

dition, according to GCSAR, Deir-Ezzor22 exhibited good technological traits. It was considered as the highest local variety in gin turnout percentage and the most temperature tolerant at vegetative stage compared to the other cotton varieties. Moreover, Sharaf et al. (2009) reported that the highest observed genetic similarity was between Deir-Ezzor22 and Raqqa5 varieties $(93.2 \%$ and $87 \%$ ) according to RAPD and ISSR markers data respectively. The latter investigation however did not mention the same pattern between the two previous varieties using AFLP marker.

Previously, Kohel (1998) applied NIR to predicate oil content in six cottonseeds lines. Other investigation focused on NIR technique for determination of free gossypol in cottonseed meal (Lordelo et al. 2008). Cottonseed meal can be an attractive alternative protein source for poultry diets. More recently, NIR has the potential to be applied in a commercial cotton trash (hull, leaf, seed coat, and stem) classification system (Fortier et al. 2012). Diversity estimates in cultivated plants provide a rationale for conservation strategies and support the selection of starting material for breeding programs. Genome diversity was determined by AFLP using twenty-one primer pair combinations. The relationship between biodiversity at the genome and at the biochemical structure level was not sufficiently clear.

\section{CONCLUSION}

The pattern generated in NIR technique according to chemical components analysis partially correlated with the other one revealed by AFLP technique. Summarizing all results obtained from NIR and AFLP techniques, it could be concluded that chemical structures were relatively reflected in genetic variation among the tested cotton varieties. Further analyses however, are required to confirm the previous results obtained in this investigation.

Acknowledgments. The author is grateful to the Director General of AECS and the head of Biotechnology Department for their support, the GCSAR in Syria for providing plant materials, the IAEA for the financial support for this work, and the BOKU University of Natural Resources and Applied Life Sciences - Vienna where the NIR analysis was carried out.

\section{REFERENCES}

ABDALlA, A.M. - REDDY, O.U.K. - EL-ZIK, K.M. PEPPER, A.E. 2001. Genetic diversity and relationships of diploid and tetraploid cottons revealed using AFLP. In Theoretical and Applied Genetics, vol. 102, 2001, no. 2-3, pp. 222-229.

ADAWY, S.S. - HUSSEIN, E.H.A. - HANAIYA, A.E. 2006. Molecular characterization and genetic relationship among cotton genotypes: 2-AFLP analysis. In Arab Journal of Biotechnology, vol. 9, 2006, no. 3, pp. 478-492.

ADAWY, S.S. 2007. An evaluation of the utility of simple sequence repeat loci (SSR), expressed sequence tag microsatellites (EST-SSR) as molecular markers in cotton. In Journal of Applied Sciences Research, vol. 3, 2007, no. 11, pp. 1581-1588.

BADIGANNAVAR, A. - MYERS, G. - AGCENTER, L.S.U. - BATON-ROUGE, L.A. 2010. Genetic analysis of AFLP markers associated with seed quality traits in Upland cotton (Gossypium hirsutum). In 2010 Beltwide Cotton Conferences : proceeding from conference. New Orleans, Louisiana, January 4-7. Nat. Cotton Counc. Am., Memphis, TN.

BOtstein, D. - White, R.L. - SKOLINCK, M. - DAVIS, R.W. 1980. Constraction of a genetic linkage map in man using restriction fragment length polymorphisms. In American Journal of Human Genetics, vol. 32, 1980, no. 3, pp. 314-331.

CHAUDHARY, L. - SINDHU, A. - KUMAR, M. - KUMAR, R. - SAINI, M. 2010. Estimation of genetic divergence among some cotton varieties by RAPD analysis. In Journal of Plant Breeding and Crop Science, vol. 2, 2010, no. 3, pp. 39-43. 
DOYLE, J.J. - DOYLE, J.L. 1987. A rapid DNA isolation procedure for small quantities of fresh leaf tissue. In Phytochemical Bulletin, 1987, no. 19, pp. 11-15.

FORTIER, C. - RODGERS, J. - FOULK, J. - WHITELOCK, D. 2012. Textile technology: Near-Infrared classification of cotton lint, botanical and field trash. In Journal of Cotton Sciences, vol. 16, 2012, no. 1, pp. $72-79$.

HUSSEIN, E.H.A. - AL-SAID, M.S. - HANAIYA, A.E. MADKOUR, M.A. 2002. Genotyping Egyptian cotton varieties (G. barbadense) using molecular markers. In Biotechnology and sustainable development voices of the south and north conference held at the Bibliotheca Alexandrina Conference Center, March 16-20, Alexandria, Egypt. 2002.

HUSSEIN, E.H.A. - MOHAMED, A.A. - ATTIA, S. - ADAWY, S.S. 2006. Molecular characterization and genetic relationships among cotton genotypes 1 RAPD, ISSR and SSR analysis. In Arab Journal of Biotechnology, vol. 9, 2006, no. 2, pp. 313-328.

HUSSEIN, E.H.A. - MARWA, H.A. - HUSSEIN, O.M.H. - ADAWY, S.S. 2007. Molecular characterization of cotton genotypes using PCR-based markers. In Journal of Applied Sciences Research, vol. 3, 2007, no. 10, pp. 1156-1169.

JACCARD, P. 1908. Nouvelles recherches sur la distribution flora. In Bulletin de la Societé Vaudoise des Sciences Naturelles, vol. 44, 1908, pp. 223-270.

KALIVAS, A. - XANTHOPOUlOS, F. - KeHAGiA, O. - TSAFTARIS, A.S. 2011. Agronomic characterization, genetic diversity and association analysis of cotton cultivars using simple sequence repeat molecular markers. In Genetic and Molecular Research, vol. 10, 2011, no. 1, pp. 208-217. DOI 10.4238/vol10$1 \mathrm{gmr} 998$

KHALIGHI, M. - ARZANI, A. - POURSIAHBIDI, M.A. 2008. Assessment of genetic diversity in Triticum spp. and Aegilops spp. using AFLP markers. In African Journal of Biotechnology, vol. 7, 2008, no. 5, pp. 546-552. DOI: 10.5897/AJB07.837

KOHEL, R.J. 1998. Evaluation of near infrared reflectance for oil content of cottonseed. In Journal of Cotton Sciences, vol. 2, 1998, no. 1, pp. 23-26.

LEWIS, H. 2001. A review of yield and fiber quality trends and components in American upland cotton. In Proceedings of the Beltwide Cotton Conference, January 9-13, Anaheim, CA. National Cotton Council of America, Memphis, TN, USA, pp. 1447-1453.

LORDELO, M.M. - SHAABAN, S.A. - DALE, N.M. CALHOUN, M.C. - VENDREL, P.F. - DAVIS, A.J. 2008. Near infrared reflectance spectroscopy for the determination of free gossypol in cottonseed meal. In The Journal of Applied Poultry Research, vol. 17, 2008 , no.2, pp. 243-248. DOI: $10.3382 /$ japr.200700078

MAY, O.L. - BOWMAN, D.T. - CALHOUN, D.S. 1995. Genetic diversity of U.S. Upland cotton cultivars released between 1980 and 1990. In Crop Sciences, vol. 35, 1995, no. 6, pp. 1570-1574. DOI:10.2135/cropsci $1995.0011183 \times 003500060009 x$
MEREDITH, W.R. 2000. Cotton yield progress - why has it reached a plateau. In Better Crops, vol. 84, 2000, no. 4 , pp. 6-9.

MUNCK, L. 2009. Breeding for quality traits in cereals: A revised outlook on old and new tools for integrated breeding. In "Cereals" : Handbook of Plant Breeding M.J. Carena (ed.) Springer Publishers, New York. 2009, pp. 333-366.

POWELL, W. - MORGANTE, M. - ANDRE, C. HANAFEY, M. - VOGEL, J. - TINGEY, S. - RAFALSKY, A. 1996. The comparison of RFLP, RAPD, AFLP and SSR (microsatellite) markers for germplasm analysis. In Molecular Breeding, vol. 2, 1996, no. 3, pp. 225-238. DOI: 10.1007/BF00564200

RANA, M.K. - SINGH, V.P. - BHAT, K.V. 2005. Assessment of genetic diversity in upland cotton (Gossypium hirsutum L.) breeding lines by using amplified fragment length polymorphism (AFLP) markers and morphological characteristics. In Genetic Resources and Crop Evolution, vol. 52, 2005, no. 8, pp. 989-997. DOI: $10.1007 / \mathrm{s} 10722-003-6113-6$

SALEH, B. 2012a. Biochemical and genetic variation of some Syrian wheat varieties using NIR, RAPD and AFLPs techniques. In Journal of Plant Biology Research, vol. 1, 2012, no. 1, pp. 1-11.

SALEH, B. 2012b. Effect of salt stress on growth and chlorophyll content of some cultivated cotton varieties grown in Syria. In Communications in Soil Science and Plant Analysis, vol. 43, 2012, no. 15, pp. 1976-1983.

SHARAF, A.N. - EL-KADI, D.A. - ALATWANI, H.F. GAMAL EL-DIN, A.Y. - ABD EL-HADI, A.A. 2009. Genetic studies on some cotton genotypes using DNA molecular markers. In $4^{\text {th }}$ Conference on Recent Technologies in Agriculture, Egypt, 2009, pp. 167-177.

STATSOFT, 2003. Statistica (Data analysis software system), version 6. Statsoft Inc. www.statsoft.com..

USDA, 2011. Syria cotton and products annual cotton report, GAIN Report, (www.fas.usda.gov).

VOS, P. - HOGERS, R. - BLEEKER, M. - REIJANS, M. - VAN-DE LEE, T. - HORNES, M. - FRIJTERS, A. - POT, J. - PELEMAN, J. - KULPER, M. - JABEAU, M. 1995. AFLP: a new technique for DNA fingerprinting. In Nucleic Acid Research, vol. 23, 1995, pp. 4407-4414. DOI: $10.1093 / \mathrm{nar} / 23.21 .4407$

WESLEY, I.J. - BRIAN, G.O. - LARROQUE, O. - BEKES, F. 2008. Measurement of the protein composition of single wheat kernels using near infrared spectroscopy. In Journal of Near Infrared Spectroscopy, vol. 16, 2008, pp. 505-518.

WILLIAMS, P.C. 2002. "Near infrared spectroscopy of cereals". In J.M. Chalmers and V.R. Griffiths (Eds.), Handbook of Vibrational Spectroscopy. Wiley, Chichester, vol. 5, 2002, pp. 3693-3719.

WILSON, L.M. - WHIT, S.R. - IBANEZ, A.M. - ROCHEFORD, T.R. - GOODMAN, M.M. - BUCKLER, E.S.I.V. 2004. Dissection of maize kernel composition and starch production by candidate gene association. In Plant Cell, vol. 16, 2004, no. 10, pp. 2719-2733. DOI: $10.1105 /$ tpc. 104.025700 